\title{
Social Psychology of East Timor's Nonviolent Democratic Transition: View From the Inside
}

\author{
Cristina Jayme Montiel
}

Ateneo de Manila University, Manila

\author{
Abilio Belo \\ Habitat for Humanity, East Timor
}

\begin{abstract}
Social psychological aspects of the East Timor peace and liberation movement were studied by Sin-depth interviews of key liberation leaders, using 20 open-ended questions in Tetum, the local language. Activist-leaders shared common beliefs: liberation as a prerequisite to development, unity, and possibility of peace through peaceful means. They told stories of acute self-suffering during imprisonment and torture; of their hopes, and courageous moments in the struggle. Human rights and Catholic faith ranked high in their shared values. Peaceful demonstrations, intergroup diplomacy, rallying international support, political and peace education towards consciousness transformation and housing refugees were liberationist nonviolent activities. Four important lessons were learned: advocacy to conscientise the people, practice of nonviolence, involvement of different sectors of society, and engaging the international community.
\end{abstract}

A colony of Portugal for 450 years, East Timor was proclaimed independent on November 28, 1975 by the Frente Revolucionaria de Timor-Leste Independente (Revolutionary Front for an Independent East Timor), more popularly known as the FRETILIN. FRETILIN enjoyed popular support from the local population and acted as the legitimate government of East Timor after the proclamation of its independence from Portugal (McGuinn, 1998).

On December 7, 1975, nine days after the proclamation of independence, Indonesia launched a full-blown attack on East Timor. The Indonesian army forced FRETILIN and its armed group, the Farcas Armadas de Libertacao National de Timor-Leste (Armed Forces for the National Liberation of East Timor) or the FALINTIL, to retreat to the mountain jungles. The Indonesian army occupied coastal towns, established resettlement camps, and subjected the Timorese to forced labour. Indonesia then established a provisional government with the Popular Democratic Association of East Timor (APODETI) leader as governor. In Dili, East Timor, the Indonesian government set up a People's Representative Council of the Region of East Timor with 28 delegates.
East Timor became divided into pro-independence and pro-integration (with Indonesia) Timorese. FRETILIN and the FALINTIL were soon joined by Catholic Church leaders, youth and student activists, nongovernmental organisations (NGOs) such as the National Council for Timorese Resistance (CNRT), and other civilian groups.

From 1975 to 1988, Indonesia closed East Timor to the world. Even after 1988, however, Indonesian forces occupied East Timor. Widespread human rights transgressions by Indonesian militaries continued unabated until East Timor's Independence Day in 2002. In 2002, East Timorese celebrated their Independence Day, with FRETILIN leader and 6-year political detainee, Xanana Gusmao, as the country's new president.

The active peace and liberation movement in East Timor emerged within the context of systemic and direct violence, extreme hardship, despair, and suffering under Indonesia's military occupation. Our study aimed to develop a deeper understanding of the human terrain of East Timor's nonviolent transition. We viewed East Timor's political transition from the lens of activist leaders of the local liberation movement. 
Using a social psychological perspective, we focused on the following aspects of East Timor's liberation movements: (a) subjective factors, particularly cognitions, emotions, values, and spirituality; (b) behavioural components, specifying behaviours used to promote active nonviolence and to counter violence; and, (c) organisational dynamics, including building political unity amidst diversity, and charismatic leadership styles.

\section{Method}

\section{Participants}

Seventeen respondents, selected because of their active participation in the movement, were interviewed indepth. The sample consisted of fourteen men and three women with ages ranging from 26 to 49 years old (mean age, 36.4 years old; $S D, 6.7$ ). While most of the respondents lived in Dili, East Timor, one of the respondents stayed in Baucau, East Timor. Respondents were East Timorese activist-leaders of the liberation movement, as well as influential in their own sectors, Church leaders, chairpersons of political institutes, directors of East Timor peace programs, staff members of East Timor NGOs, underground activists and political leaders of the Special Armed Forces of East Timor. Table 1 lists the organisations and number of leaders who were interviewed for this research.

\section{Interview Guide}

The interviewer used a semi-standardised interview guide consisting of 20 open-ended questions (italicised) in Tetum, the East Timorese local language. Following are some examples of open-ended questions in Tetum, with corresponding English translations:

Saida mak ita boot hatene kona ba activo movimento da paz e libertasaun iha Timor Leste? (How do you per- sonally define the active peace and liberation movement in East Timor?)

Sentimento saida mak ita boot experiensia wainhira halao movimento da paz e libertasuan iha Timor Leste nia laran? (What were your personal feelings when you were actively involved in the active peace and liberation movement in East Timor?)

\section{Procedure}

In politically-sensitive researches, one should be aware of the historical context of data collection. We ran interviews during the acutely vulnerable period sandwiched between the post-referendum massive violence by Indonesian militaries on the local people, and the declaration of East Timor independence in 2002. Hence, it was extremely difficult to enter East Timor. For example, the second author of this paper was temporarily detained by Indonesian immigration at the Bali airport, en route from Dili to Manila. He was able to gain his freedom by bluffing his way through interrogation.

Because of the volatile situation during East Timor's political transition, it was likewise a challenge to gain the trust of liberation leaders, and talk with them about their experiences. The researcher contacted the respondents primarily through their organisations and through their participation in the Conferencia General de Quadros (General Conference of FRETILIN Branch in Dili, East Timor), a five-day conference sponsored by the FRETILIN and held in Dili, East Timor from May 15 to 20, 2000. He personally delivered interview request letters to prospective respondents. Interview schedules were then arranged according to the respondents' convenience.

Interviews were conducted in different venues including FRETILIN conference rooms, the conference site of the Conferencia General de Quadros (since most

\section{Table 1}

List of Organisations and Number of East Timorese Leaders Interviewed Per Group

\begin{tabular}{lc}
\hline East Timor organisations/individuals & Number of interviewees \\
\hline Political or human rights organizations / izndividuals & 2 \\
Frente Revolucionaria de Timor-Leste Independente & 1 \\
$\quad$ (Revolutionary Front for an Independent East Timor) (FRETILIN) & 1 \\
Armed Forces for the National Liberation of East Timor (FALINTIL) & 3 \\
$\quad$ Radio FALINTIL & 1 \\
$\quad$ National Council of Timor Resistance (CNRT) & 1 \\
Sahe Institute for Liberation & 1 \\
$\quad$ Communication Forum for East Timorese Women (FOKOPERS) & 1 \\
$\quad$ Yayasan HAK1 & 1 \\
Liberation leader & 3 \\
East Timor Catholic Church organisations/individuals & 1 \\
$\quad$ Caritas Dili & 1 \\
Diocese of Bacau & 1 \\
\hline Catholic Bishop & 17 \\
\hline United Nations Transitory Authority of East Timor (UNTAET) & 1 \\
\hline
\end{tabular}


of the respondents attended the conference), religious offices such as the Bishop's office in Baucau and the Diocese of Dili, and offices of nongovernment organisations such as Caritas Dili East Timor and the Sahe Institute of Liberation. The interview duration ranged from 30 minutes to one hour and 30 minutes.

Data analysis involved qualitative methods such as transcription, theme identification, sorting, and clustering. The researcher/interviewer translated the interview discussion into the English language and transcribed the entire interview verbatim. The voluminous qualitative data were then sorted into tables and clustered according to categories from a social psychological interpretative lens.

\section{Results}

What were the social psychological experiences of East Timor activists, in the midst of the direct and systemic violence they suffered? This section looks at cognition, emotions, values, and behaviors associated with leaders and members of the liberation movement.

\section{Cognitions: Toward Peace and Liberation}

We identified four major components of the East Timorese's beliefs about peace and liberation. These were: (a) liberation as a prerequisite to development; (b) independence as inherent to human dignity; (c) cognisance of the need for unity; and (d) a strong belief that peace through peaceful means is possible.

\section{Liberation as a Prerequisite to Development}

Activist-leaders believed that political liberation as well as individual freedoms were necessary to East Timor's survival as a people. Respondents repeatedly emphasised the shared goal of independence from Indonesia's foreign occupation. In addition, the Timorese leaders recognised the importance not only of independence, but also of freedom. Individual freedoms were perceived to be attainable through a democratic system of government.

Liberation and freedom stood as prerequisites to national development. Respondents from organisations such Caritas Dili, Yayasan HAK, FRETILIN, National Council of Timor Resistance (CNRT), Radio FALINTIL, Sahe Institute for Liberation, and FALINTIL described the 24 years of Indonesian military occupation as a primary cause of the persisting local agricultural, educational and economic problems.

\section{Independence as Inherent to Human Dignity}

East Timorese leaders believed that independence was tantamount to dignity. Several respondents understood the quest for independence as a social responsibility tasked upon every generation of their people. A Catholic leader stressed that underlying the movement's political objectives stood the desire to regain the shattered human dignities of East Timorese. Respondents likewise talked about the loss of social dignity with the transgressions of culture, values and traditions. Thus, preservation of human dignity both pertained to the East Timorese's search for their value as individuals and as a collective people.

\section{Cognisance of the Need for Unity}

Respondents saw that organisational unity was necessary to attain the movement's political goals. As one religious leader put it, it was necessary to strive for unity and the common good because, 'if we work our own ways, we bump into each other [rather] than walk together'. A respondent affiliated with Yayasan HAK talked about a desire to, 'develop and strengthen the national unity- to be one people, one heart and one desire'.

\section{Strong Belief That Peace Through Peaceful Means is Possible}

Although activist-leaders believed that peace through peaceful means was possible, some individuals and political movements engaged in democratic transitions used violence across varieties of historical moments of the struggle, and different seasons of one's personal life. However, at the historical moment of this study's data collection, the interviewees affirmed their belief in the viability of nonviolent political change.

One religious leader likened East Timor's movement to that of the Philippines' 1986 People Power movement where the Filipino people succeeded in toppling the Marcos dictatorship through peaceful protest actions. With successful models in other parts of the globe, the respondents deemed it possible to attain liberation through nonviolent means.

\section{Emotions: Acute Suffering, Hope and Courage Experiencing Political Self-Suffering: Imprisonments, Tortures and Deaths}

Members of the liberation movement suffered torture, house burning and death under Indonesian military rule. Respondents talked of how Indonesians set up resettlement camps to prevent uprisings, destroying buildings and demolishing houses of the common Timorese in the process. Many local people were left without shelter and sufficient food. The activist leaders also narrated how Indonesian militaries subjected East Timorese to forced labour; used civilians as human shields in their fight against insurgents; and forced East Timorese women to take birth control.

Personal stories of self-suffering abounded. A respondent from Yayasan HAK related his experience of being imprisoned and tortured by the Indonesian military. Another FRETILIN member reported how her husband was captured and how he eventually disappeared, leaving her to fend for her son and herself amidst the military's threats of rape. A leader of the Women's Movement for East Timor (FOKUPERS) witnessed soldiers pointing a gun to her brother's head, beating him and threatening to shoot him. 
Decades of Indonesian occupation took their toll on the East Timorese. A respondent from FALINTIL described how the people felt weary and worn out. The 24 years of direct violence and colonial oppression had created a pit of accumulated anger and bitterness in the hearts of the local people.

\section{Hope and Courage}

Despite chronic social aggression and adversity, East Timorese continued to demonstrate hope and courage. They felt proud that their small country sustained a long and successful struggle against their oppressors, with little external support. Optimism was further triggered by key historical events, such as former Indonesian President Suharto's resignation, as well as the belief that no dictatorial regime is ever eternal ('I Feel Extremely Optimistic', 1998). One respondent capsulised the locals' sense of social hope with a Portuguese quote, ' $[P]$ edra dura agua mole, tanto bate tenqui fura', which means, 'that although the stone is hard, water will beat it and penetrate its essence'.

Activists likewise demonstrated striking human courage. A respondent from CNRT talked about how fellow activists possessed the spirited desire to fight for self-determination, against all cruel adversities. To them, the threat of direct and systemic violence was a reality that simply had to be overcome.

\section{Politico-Cultural Values Valuing Human Rights}

East Timor's liberation movement was not only against Indonesian occupation, but also in support of fundamental human rights. One may note that liberation movements in other societies may be strongly anticolonial (i.e., nationalist) but not necessarily democratic (i.e., free). Respondents talked about valuing basic social values such as justice, freedom, truth, peace, love, liberty, courage, fair play, and equality. The use of forcefully just yet peaceful means during transition optimised the protection of these social values.

\section{Catholicism}

Respondents from different factions shared the view that aside from encouraging the use of nonviolent methods, the Church also kept hope alive among the East Timorese. Catholic scripts related to peace and liberation were propagated through catechetical instructions. Examples of such scripts included instructions to love one's neighbour as one's self, maintain patience and courage amidst sufferings, and believe in the power of prayer. During the struggle, sacramental celebrations of the Holy Mass and confession encouraged people to reconcile with the Lord and seek inner peace. A Catholic leader explained that amidst temptations to fight back, followers of the movement turned to the Church's teachings to forgive their adversaries' trespasses.

\section{Behavioral Components of the Active Peace} and Liberation Movement in East Timor

Collectively and separately, disparate groups employed a wide range of culture-based nonviolent political actions. The Catholic Church, youth groups and student associations, FRETILIN and other political parties, nongovernment organisations, women's groups and human rights activists played vital roles in the social movement. We now describe modes of forceful nonviolent action during the democratic transition.

\section{Peaceful Demonstrations and Intergroup Diplomacy}

The liberation movement initiated public protests, prayer rallies, diplomatic campaigns, boycotts of government activities, lobbying for human rights, and peaceful dialogues with political factions. It also called for active ceasefire and cessation of hostilities, the withdrawal of Indonesia's military forces in East Timor, and the granting of a referendum to vote for East Timor's independence.

Even at the height of inter-group conflicts, liberation leaders called for dialogue. One respondent from CNRT shared that when the Democratic Union for East Timor (UDT) retreated to Indonesia, an influential CNRT leader sent a message to the UDT requesting for a dialogue to settle their political differences. FALINTIL Commander-in-Chief, Xanana Gusmao, also upheld the practice of political dialogue. In 1983, he initiated a process of dialogue with Indonesia and thus, was able to achieve one month of peace for East Timor.

When collectively violated, the movement responded with forceful peace. For example, when student leader Sebastian Gomes was killed in October 28, 1991, the East Timorese staged a peaceful demonstration to commemorate Gomes' death. Shockingly, the peaceful demonstration ended with the Santa Cruz massacre. Nevertheless, East Timorese continued their political struggle through diplomacy, street demonstrations, and documentation.

\section{Rallying for International Support}

Crucial to the movement's success was its ability to gather support from international organisations. Respondents told stories of how they appealed for support from the international community. For example, nongovernment organisations, the Catholic Church, and youth and women's groups collected violence-related data and brought the East Timor situation to international attention. Solidarity networks in different countries materialised to put pressure on the Indonesian government concerning its human rights transgressions in East Timor.

By 1992, East Timor solidarity movements around the world had emerged. Sympathisers from the US founded the East Timor Action Network while supporters from Canada set up the East Timor Alert Network. Other groups in countries such as Japan, Australia, United 
Kingdom, New Zealand, Malaysia, Thailand, Brazil, South Africa and the Philippines likewise formed their own solidarity movements for East Timor. A respondent affiliated with Caritas Dili claimed that there also existed Indonesian solidarity groups, especially nongovernment organisations that worked for the freedom of East Timor. Such demonstrations of support made the East Timorese feel that they were not alone in their struggle, and strengthened them in the face of painful adversities.

Respondents also cited one heartening moment that greatly inspired the local people in their nonviolent struggle for peace and liberation: the triumph of East Timorese leaders Bishop Carlo Belo and Dr Jose Ramos Horta as Nobel Peace Prize recipients in 1996. To the people, the awards came as an inspiration and assurance that efforts to maintain an active nonviolent stance against Indonesian military rule did not go unnoticed and that active nonviolence was a viable way to attain peace and liberation.

\section{Consciousness-Transformation and Peace Education}

Apart from inter-group dialogues, mass peaceful rallies, and international support, movement leaders used sociopolitical and peace education to transform national consciousness toward the collective goals and values of liberation. One respondent narrated how FRETILIN ran political education programs to empower illiterate groups.

In the same way, nongovernment organisations in East Timor actively educated the local population concerning national issues so as to encourage participation in the movement. Nongovernment organisations like Yayasan Hak Dili (Human Rights Foundation in Dili), Sahe Institute for Liberation Dili, and Forum for East Timor (FORTILOS), launched massive human rights education campaigns. Further, the Women's Movement for East Timor (FOKUPERS), concentrated on promoting, building and reconstructing peace through seminars in other countries like the Philippines.

Youth groups also held political discussions about social change. Student associations worked hard to socialise, educate, and raise people's consciousness about the deeper meanings of peace, freedom and independence. Respondents from the Diocese of Bacau and from FALINTIL narrated how students travelled around East Timor and conscientised provincial village folk about the country's national issues. East Timorese youth also represented their people's struggles in international forums sponsored by the Church and attended by other youth groups from Kosovo, Rwanda, Konggo and other conflict-ridden societies.

\section{Housing Refugees}

Sympathetic groups and individuals housed several Timorese and other refugees wanted by the Indonesian government. Sister Marlene Bautista, a Philippine-born
American nun of the Salesian order, along with Sister Paola Battagliola, an Italian nun and Mother Superior of the Salesian convent in Dili, sheltered and protected over 400 refugees in their convent. The parents of independence leader Xanana Gusmao sought refuge with the nuns as pro-Indonesian death squads hunted the Gusmao couple (Eads, 2000).

Although liberation-related behaviours were carried out by diverse groups that had little formal linkages and organisational structures, East Timor's social movement moved forward as if in singular motion toward independence and freedom. The following section points out some organisational features of East Timor's democratic movement.

\section{Organisational Characteristics of East Timor's Nonviolent Liberation Movement}

\section{Shared Vision: An Aligning Force Among Diverse Groups}

East Timor's nonviolent political action was a product of diverse (and politically passionate) sectors of society. In spite of such inter-group complexity, the various groups moved forward with one goal. The alignment seemed to come from a shared consciousness within the broad liberation movement; they would work for independence from Indonesia and the creation of a free country. A respondent from Sahe Institute for Liberation admitted that although the liberation movement had no official structure or unified national platform, cooperation and systematic operations emerged from a shared political vision - that of fighting for the country's freedom. Strikingly, even during the absence of a distinct leader, different sectors organised themselves and initiated their own activities.

At this point, allow us to emphasise the crucial role of political education campaigns toward forceful nonviolent change. These workshops and seminars aligned the shared consciousness of East Timorese toward a unified goal of independence from Indonesia. Hence in spite of its diverse political and civic groups, the liberation movement moved forward, with a singular goal to free East Timor from Indonesia.

\section{Leadership Styles}

Respondents claimed that East Timor's peace and liberation movement benefited significantly from the leadership of dynamic personalities who held: (a) a proclivity for the democratic process; (b) a social forcefulness tempered by gentle spirituality; and, (c) an ability to lead by inspiration.

Examples of democratic leadership abound. Nobel Peace Prize recipients Bishop Carlos Belo and Dr Manuel Ramos Horta, along with FALINTIL Commander-inChief Xanana Gusmao and other leaders of FRETILIN, held discussions and consultations with the local people and undertook decision-making through a vote by the majority. One respondent from Caritas Dili narrated how Bishop Belo and Dr Ramos Horta would always ask 
people questions such as, '[W]hat is peace?', in an effort to raise the people's awareness regarding the issues surrounding them.

However, although the leaders employed a predominantly democratic leadership style, they would at times flex their methods according to the political and cultural situation. One respondent from CNRT cited the eclectic character of the movement's leaders, employing an authoritarian style, which sometimes turned democratic, or paternalistic.

When discussing leadership, respondents from the Women's Movement for East Timor (FOKUPERS), Caritas Dili and FRETILIN explained that charisma involved a spiritual and inspirational kind of leadership. Elaborating on charisma, the respondents talked about a person's sincerity, diplomacy, and dedication to working as vital to effective liberation leadership. Among those viewed as charismatic were Bishop Belo, Bishop Nascimento, Dr Ramos Horta, and Xanana Gusmao. One respondent from Yayasan HAK considered FALINTIL Commander-in-Chief Xanana Gusmao charismatic because of Gusmao's ability to, 'convince the people of East Timor to obey whatever he commanded and said (...) In fact, the people [listened] to him and behaved accordingly'.

\section{Social Leadership of East Timor's Catholic Church}

Throughout the struggle, the Catholic Church stood as an institutional and personal stronghold in the lives of East Timorese. The Church and its leaders contributed considerably to nonviolent political action by: (a) publicly condemning social abuses; (b) mobilising and leading people for massive peaceful demonstrations; (c) developing and campaigning for spiritual convictions geared toward peace; (d) raising appeals to soldiers and the youth not to use arms and guns, and (e) providing sanctuary to East Timorese who were hunted by the Indonesian agents.

The Catholic Church exercised public leadership in some of the most important mass protests in East Timor. Examples of these forceful social episodes were the pro-independence demonstration during the Papal Mass held on October 12, 1989; the pro-independence protests during the 50th anniversary of the Archdiocese of Dili held on September 4, 1990; and, the march to the Santa Cruz cemetery in memory of Sebastian Gomes held on November 12, 1991 (Carey, 1995).

The Church likewise engaged in vigorous peace/sociopolitical education. Some church groups raised an awareness campaign by forming the Commission of Justice and Peace, which educated people about peace and reconciliation. One respondent from Caritas Dili attested as to how peace-related messages were delivered through seminars and workshops, as well as how pastoral letters and appeals were directed to people living in East and West Timor.
Bishop Belo, in his pastoral letter addressed to local, regional, and international organisations, to the Indonesian government, and to the Timorese people, called on everyone to sit together and dialogue. A respondent from FOKUPERS recounted Bishop Belo's appeal to create and maintain a culture of peace during the struggle. Appeals also took the form of political education and awareness campaigns to inform the local people about current issues.

The Church organised seminars involving migrants, refugees, pro-independence and pro-integration Timorese and Indonesians to discuss reconciliation, peace and justice.

\section{Engaging Grassroots and Sectoral Groups in the Struggle}

East Timor's liberation activists reached out to sectoral and grassroots groups. Respondents from Caritas Dili and FRETILIN explained that sociopolitical training enabled local people to act on their own initiative. The FRETILIN encouraged people to liberate themselves from oppression, respect democratic processes, and live peacefully as communities. This grassroots oriented approach gave rise to people's organisations and egalitarian leadership in various forms of resistance.

\section{Reflections on East Timor's Nonviolent Democratic Transition}

In this final section, we present reflections on the human face of East Timor's democratic transition, highlighting social psychological features of the political process. We base our discussion on the narratives of our activistrespondents. Our assessment of the democratic transition covers lessons learned from the liberation movement, and challenges that persist in East Timor's new democratic society.

\section{Lessons Learned from East Timor's Peace and Liberation Movement}

Years of systemic and direct violence in East Timor taught the local people politico-psychological lessons that helped them sustain the forceful yet nonviolent character of the movement. We encapsulate the political learnings in the following way: (a) conscientise the people; (b) in the everyday struggle, practice the nonviolence you preach; (c) involve the different sectors of civil society, and (d) engage the international community.

\section{Conscientise the People}

In Pedagogy of the Oppressed, Freire (1970) created the term conscientisation to show how oppressed peoples learned about social exploitations, and took action against such abuses. A vital aspect of conscientisation is the seamless interplay of theory and practice against exploitative social systems. We use the term conscientisation to describe the process of transformative political consciousness in East Timor's liberation movements. Conscientisation programs aligned group consciousness around the idea of liberation and nonviolence. 
Respondents acknowledged the vital role played by social-awareness seminars and workshops. Sociopolitical education programs produced a unified collective consciousness about social issues (Indonesian occupation and human rights abuses), political goals (independence and freedom), and common strategies for change (active nonviolence). Leaders encouraged the people to reflect on social issues and make decisions for collective action. In spite of organisational diversities and fractiousness, numerous political and civic groups moved in relative unison against Indonesian rule.

\section{In the Everyday Struggle, Practice the Nonviolence You Preach}

A most important lesson derived from the East Timor experience is that active nonviolence must be evident in the lives of those who preach it. The devotion of Catholic priests and nuns to the inseparable goals of peace and liberation exemplified the unity of theory and practice. The practice of peace was also illustrated in the Church's call for reconciliation between pro-integration and pro-independence Timorese and Indonesians.

One respondent from the Bishop's Office claimed that since acceptance of differences among the people was crucial to peace, different liberation groups needed to let go of hatred and revenge. A member of the FALINTIL noted how adversaries must not be avoided, but rather approached in the spirit of dialogue. Another respondent from FRETILIN narrated, '[I] did not confront my opponents, but I tried rather hard to talk to them and negotiate with them regarding how to come up with the best solution for creating peace together. This is because I had it in my mind to create peace with everyone'.

\section{Involve the Different Sectors of Civil Society}

The active participation of diverse segments of civil society served as a pillar of strength in the nonviolent struggle. The liberation movement was not vanguarded by political parties, but rather, embodied a unified front of self-initiating groups. The formation of the National Council of Maubere Resistance (CNRM) in 1986 brought together all East Timorese political parties and groups dedicated to independence. Despite serious inter-group tactical differences and passionate interpersonal fights, different sectors united to struggle for national self-determination. Needless to say, effective liberation leaders needed to be highly skilled in inter-group and interpersonal conflict resolution, at every stage of the struggle.

\section{Engage the International Community}

Although particular Southeast Asian governments who were members of the Association of Southeast Asian Nations (ASEAN) supported the Indonesian government, civil society and nongovernmental groups from different countries backed-up the East Timorese's call for solidarity. These solidarity networks, consisted of East Timor sympathetic groups in and beyond Asia. International pressure compelled the Indonesian government to heed the East Timorese's demand for greater autonomy.

\section{East Timor's New Democracy: Challenges Ahead}

'We have liberated our land, but we have not liberated our society', shares one respondent from Radio FALINTIL. Although activist-respondents clearly identified the Indonesian government as their main opponent, some further perceived a new breed of adversary in local opportunists and destabilisers. There were other changes in the power terrain in the new democracy. For example, according to a respondent from the Bishop's Office, the Church should no longer be at the forefront of the struggle since other institutional alternatives already existed for the movement. The dependence of the people, especially of the youth, on the Church remained an area of concern. The selfpropelling involvement of the youth in the public decision-making process needed to be cultivated in order to create a next generation of nation-builders.

Respondents frequently cited as a major shortcoming the lack of political unity and overarching organisational structure. Although members from these different organisations shared a common goal, they were not singularly organised. Consequently, they met, got together temporarily, then eventually separated ways. Inevitably, some parties turned against each other while others suffered from internal factionalism as smaller groups attempted to break the unity of the larger organisation. At the time of data collection, the National Council for Timorese Resistance (CNRT) worried that its offshoot organisation, the Republica Democratica Timor Leste (Democratic Republic of East Timor) or RDTL may extricate itself from the main political party, thereby creating a new conflict.

Members of the movement continued to appeal for unity, consultation, participation, and dialogue. They called on the people to practice peace in their personal lives, in their own homes, and in their communities. 'The active peace and liberation movement should be rooted in each Timorese', explained a respondent affiliated with Yayasan HAK. In spite of formidable challenges, East Timorese persevere. They look forward to a future of independence and freedom - a future brought about by collective selfdetermination, and fortified by their experience of active nonviolence.

\section{Final Remarks}

The story of East Timor's liberation struggle from Indonesia demonstrates how a people can stand up against formidable foreign occupiers of the local land. At the time of writing, militarised foreign occupation again looms its ominous head in other parts of the world, like Iraq. Foreign-backed political change relies heavily on firepower, re-enacts imperialism with a dif- 
ferent face, builds deep resentments and tortures the local civilian population, disempowers indigenous social identity, and calcifies authoritarian systems. Active nonviolent democratic liberation movements present a viable alternative to militarised and foreignbacked intrusions in the Majority World.

\section{Endnotes}

The second author worked on this research as a psychology graduate student at Ateneo de Manila University. He is now affiliated with Habitat for Humanity East Timor.

\section{Acknowledgments}

The authors thank the Japan Foundation Manila for generously funding this research.

\section{References}

Carey, O. (1995). The forging of a nation: East Timor. In P. Carey, \& G.C. Bentley (Eds.), East Timor at the crossroads: The forging of a nation (pp. 1-18). New York: Social Science Research Council.

Eads, B. (2000, October). A nun's story. Reader's Digest, 76, $44-52$.

Fawthrop, T. (1999, December 3). The U.N. is not listening. Asiaweek, 24, 42.

Freire, P. (1970). Pedagogy of the oppressed. New York: Herder \& Herder.

I feel extremely optimistic (1998, July 13). Time, 152(1), 32.

McGuinn, T. (1998). East Timor: Island in turmoil. Minneapolis: Lerner Publications.

Twisted referendum? (1999, June 18). Asiaweek, 25(24), 20. 